\title{
A FEMINIST APPROACH TO SPACE: HOW WOMEN "PROJECT THEIR HOME ENVIRONMENT” THROUGH VISUAL ARTS
}

\author{
A B S T R A C T
}

This paper reconsiders the relation established between (the architectural) space - the house and the woman in it, or versus it. Such a relationship is projected through visual arts, as is evident in the examples of the selected case studies. The objective of this thesis is to elaborate upon the idea that contemporary women authors use "their house" as the topic of inspiration behind works, which are quite often reminiscences of the emotional spectrum they lived during their own childhood. Furthermore, it also shows that through those works they establish their personal attitude towards the notion of "house" in general. The starting point of this paper is based on the theoretical views of Griselde Pollock, a feminist critic and theoretician of visual arts, and her analyses of "the space of femininity" and the women artists in modernism. 


\section{INTRODUCTION}

Being the place which a woman is deeply linked to, home is an architectural icon at least to the extent of what it is and how it is perceived; for example a high-rise. Home is not a house, even though in the Serbian language these two expressions are often used in an inadequate yet precise definition, and thus arbitrarily substitute each other. 'Home' is more of a concept, a utopian supposition, whereas 'house' is - a building, an architectural creation. In the Greek language the word oikos refers to the identity of a house as a building and the family inhabiting it. Home has always been assumed (and understood) as the place of female domain, the place where a woman was 'the hostess' and the area of which her activity has been limited; thus defined it (home) perpetuates the traditional family and the distribution of roles in it. Even at the early stages of childhood a woman is instructed to take care of her home, and the house as well, and for that reason she has exclusively been identified with home/house.

In psychology a woman is interpreted in terms of subjectivity, emotions, fantasies, affectation, intuition, and a man - by objectivity, insensitivity, rationality, competition. Throughout the course of the history, the spatial arrangement of the rooms inside the house has been established accordingly. The spatial schism to the male and female parts of the house comprised the untouchable and sacrosanct spaces. For "the host" they include: the study, the entertainment area and hobby room, and as for "the hostess" - she is responsible for multiple roles in various rooms: the cook in the kitchen, the serving lady in the dining room, a mother in the living room, a mistress in the bedroom. The traditional division of "the private" and "the public" - whereby" the private" was understood as something that was in the terms of status the unrecognized area of sociability, therefore, the sphere occupied by women, whereas "the public" was that area belonging to men in which power, money and authority dominated and each type of super personal super personal category - was criticized by feminist theories as, yet, the result of the interestbased (masculine) construing. For "he-feminists" (men advocating feminism) and "she-feminists" (women advocating feminisms) (as a difference from, for example the English language, in the Serbian language there are two genders - tautological contribution of a minor language!) "private", even if though having the status of the sacrosanct sociological fact, is "an ideological prison" which isolates the women from the men's public life, thus "entrapping" them into home. "Private" has a close definition, is easy to interpret, predictable, in the terms of status it is an unrecognized area of sociability in which women dwell, while "public" is the domain belonging to men in which the speech of power, authority, potency and other super personal categories dominate. ${ }^{2}$ 
Feminism, as a paradigm of the idea on society, is the science which implicitly or explicitly supports the common, comprehensive system of images on the world from the perspective of a woman. Feminist theories have been established within art, philosophy, epistemology, psychoanalysis, etc. and are related to the subject of feminism. Feminism as practice which studies the issues of gender identities ${ }^{3}$ was established at the end of the nineteenth century through the fight for existential, political, social and professional equality of women. On one part, it concerned the platform on which the political struggle for establishing women-s rights was fought, primarily the right to education, the right to work and to partake in political decision-making process, and on the other part, it concerned the micro-political platform from which the battle was fought for the right to select their sexual partner - whether heterosexual or homosexual. In a theoretical sense, the work of the feminist philosopher Simone de Beauvoir was of exceptional significance towards development of feminism in the fifties and sixties of the twentieth century, ${ }^{4}$ which was founded partly in existentialist philosophy and partly in Marxism.

The contemporary feminist's theory was established in mid-sixties of the twentieth century by liberalization of the capitalistic society, at which moment, in until that time puritan capitalistic bourgeois society, the marginal, plural communities (artistic, sexual,...) were formed, which had not existed before. The feminist theory within art (of the work and of the criticisms), philosophy, epistemology, psychoanalysis was established, which then further branched out into two direction: one direction was the radical feministic and activist one, and the other direction - the direction of politically correct feminism. Julia Kristeva, Ellen Sixu and Luce Irigaray established post-feminism in the French post-structuralism, the American counterpart of which was represented by the work of the theoretician Shoshana Felman (Ms).

In the eighties of the twentieth century there was a parallel establishment, on one part of the feminist studies postulating the concept of the female social identity and, on the other part, the female studies which established the academicism of the feminists studies, namely, they study the reception of feminism on the university level. Phrased otherwise, they established feminism within the frames of the university discourse so that the university discourse itself now became the issue from the position of female identity.

Feminism, therefore, is also a type of spatial politics, since that which it is finally all about in it - the dichotomy between the private and the public takes the central part in almost two-centuries long feminist struggle. 
Leon Battista Alberti wrote about the layout of the rooms in private houses in "Ten Books on Architecture". This book was written in the middle of the fifteenth century and nowadays is considered as the text which has promoted architecture into free arts; when read, however, from another angle of perception and in other time, in the parts where Alberti dwells on description of the private houses and the layout of the rooms in them, at the point of section of the spatial arrangement and the system of supervision achieved by such layout - an issue of gender ${ }^{5}$ is discerned, or, more specifically, the role of the gender in the discourse of space and the role of the space in the discourse of gender.

"I remember reading in the historian Probus work" - writes Alberti in the Fifth Book - " that it was a custom among the Greeks that women were never seated at table if there was anyone else except the relatives; and that the rooms for women were part of the house where man never set their foot, except for the closest relatives. And, indeed, to my mind, the rooms for women should be sacred as the places devoted to religion and demureness. I am all for it that the virgins and young damsels should have specially designed rooms decorated and adapted in the neat and delicate manner to release their gentle thoughts so that they would exhaust themselves the least possible. The land-lady should have the rooms in which she should be able to hear what goes on in the house... Husband and wife should have separate rooms, not only because the wife, whether she be lying in bed or would nurse some other inconveniences, would not cause any discomfort to her husband,, but also because during summer any of them may lie down alone whenever he or she desires. Each of these rooms should have its own door and they should both share a common passage so that one can go to the other without being seen. The wife's room is connected to the wardrobe, and the husband's to the library.... Next to the place where treasure is secured there is a place for the boys; and next to the wardrobe - a room for the girls; next to it is the room for the nannies... The sons sixteen or seventeen years of age should have their rooms across from the guest rooms so that they have the possibility of talking to the guests and meeting them." ${ }^{\circ}$ This part of the text has been separated from the rest and has been wrapped in there-layers by formulation of yet the first sentence in which, first, Alberti remembers the words of another author who alone conveys the tradition of an ancient custom...Thus Alberti redirects the responsibility for this argument from himself to some ancient predecessors, keeping modestly, only here and there "...to my mind". Isolated and separated, this passage according to Mark Wigley "is located in the pre-architectural domain of the social order where the law of the house precedes the house itself" 
Even though the space of the house is reserved for women, and the space of the public for men, it has been interpreted that the woman leaving the house becomes thereby more of a woman, rather than being constrained by the limits imposed by the masculine realm: her sexuality, namely, is no longer controlled by the house. It is actually stated, that women lack internal self-control granted to men as an expressive sign of their masculinity; unable to control herself, a woman is presented as the one that has to be controlled by being restrained. ${ }^{8}$ One of the ways of institutionalization of this control is through marriage understood as a process of taming. In that way, architecture becomes the obvious place to control female sexuality where a woman is restrained to the house, and the girl to her room. Finally, marriage is defined as "the life under the same roof" (marriage is the reason for building the house), and the house the space for its institutionalization, and - besides protecting the family against the outside elements - it also isolates a woman from other men.

\section{FROM THE HOUSE OF DOLLS9 TO THE ROOM OF ONE'S OWN ${ }^{10}$}

Griselda Pollock"11 in her " Modernity and Spaces of Femininity", her often cited essay in feminists literature, discusses the works of the female artists from the times of modernism, and in it maps the distinction of the male and female spheres by separating them into 'public' and 'private'. That division efficiently outlines the structuring of the bourgeois way of life. One phenomenon of this new experiences of modernism, flaneur, a Baudelaire's term of reference which is applied to an indifferent (apathetic) walker enjoying the liberty of an incognito being in a crowd, such liberty which has never been ${ }^{12}$ granted to women. Baudelaire describes Paris in a manner of a painter impressionist who, guided by the paths of amusement, offers sexualized travel through the city from the center to the suburbs. Bourgeois woman was defined by "another, non-social space, the space of feelings and duty from which money and power have been banned"13 and the public/private division acts on many levels and structures the meaning of the notions of male/female within the mythical limits.

Using Baudelaire's categorization from "The painters of the Modern Life" ( which is related to the review of the motives of the painters impressionist: Manet, Renoir, Monet), Griselda Pollock provides a table survey of artists, both male and female, of the Impressionism in relation to the fields of home as the motives (living room, patio, balcony) which they paint; according to this table, the preoccupation of either with the house as a problem is equal. ${ }^{14}$ The interest of the artists when interpreting the "female spaces" is equal to the interest of the female artists from the times of Impressionism, however the 
manner in which the topic is approached is quite different. Spatial organization of the composition, particularly in the paintings of the female artists Mary Cassatt and Berthe Morisot which are analyzed by Griselda Pollock, is different than the male artists. The paintings of these female artists are most often concerned with the juxtaposition of two spatial systems on the same canvas, two parts of the space outlined with balustrade, most often emphasized by the structure which, however, do not mark only the border between the public and the private, but also between the space of masculinity and the space of femininity, and feminine nature. Written on those two levels it not only says which spaces are accessible to men and which ones to the women, but also what relation men and women have towards the space they find themselves within.

These female painters paint exclusively themselves, women ${ }^{15}$ and likely the children; the men - never. Their motives are other women or maidens, which they paint in the space of home with " the assurance of knowledge of the everyday life and customs which not only form the spaces of femininity but collectively mark them with good phases in the life of a woman"16 The female painters of Impressionism paint the private spaces and the women in them, but the women models are not as with the artists just pure corporeity exposed to the eyes of the voyeuristic observers, but are often, presented as the subject, the bearer of a certain action.

Even though being female private spaces (bedroom, bathroom, wardrobe), these spaces are not only available to women, but to men as well: in other words, there is no exclusive female space. In the history of architecture, the first, real private spaces, are the studies, small enclosed rooms, which had the entrance only from the man's room in the house; nobody else was given access to them - they are tiny spaces for the intellectuals ${ }^{17}$ beyond any possible sexuality. They originated by transformation of a piece of furniture in the bedroom, a locked writing desk, in the fourteenth century and by the fifteenth century they became almost a mandatory place in each house..$^{18}$ At that time wardrobe and dressing room which was entered from her bedroom belonged to the woman, however, that space was not her personal one given that the children, servants and nannies had access to them. With the emergence of the man's study the woman no longer had the control over the entire space of the house, her space of perception now spanned from the locked study door as far as the house front door; she no longer had access to the room preserving the secrets of the house and the family. The man, not only kept the documents and official papers directly concerning the family (contracts, personal documents, 
family tree, details of family relationships, data on the ancestors) in this space, he literally produced them there as well. For that reason the private space is the space of writing in which the author isolates himself from the outside world withdrawing himself into the house, and from the house into his own study. Thus the existence of A Room of One's Own, Virginia Wolf, in the essay "The Room of One's Own" presumed as the condition to be a writer, that a woman is a writer, unless she accepts in defeatist manner to live the life of Shakespeare's sister $^{19}$ : " a room of one's own, not to mention a quiet room not letting any sound in..." 20

For Adolf Loos a house is a stage for the family theatre, a place where people are born, where they live and die. In Prague in 1930 he designed the Müller house and in it A Room for the Lady (Zimmer der Dame). In this house a series of rooms articulating around the stairway, have a an increasing degree of privacy, from the guest room, via dining room and study to the Room for the Lady. ${ }^{21}$ The room which should have been the most intimate one was placed at the entrance, has a window with a dining room view, is close to the social activities rooms in the house, is located where anyone entering the house can easily be seen; it is far removed from the center of the house, has the character equally both of the sacred place, and, also of the control point. Loos produces comfort, even though paradoxically, with the two seemingly opposite situations, intimacy (closeness) and control.

\section{Femmage}

In contemporary art the relation between the male and female artists towards the topic of the "house" is no longer established in the manner in which Griselda Pollock explained the treatment of the private area by the male and female artists in modernism. For example the works of the women artists treating the problem of the "house" was treated as femmage by the art historians Miriam Shapiro and Melissa Meyer. Femmage is the term they coined in 1997 to define the collage process which the women have been occupied with in the households for centuries; at the same time, these are various types of collage techniques accepted by female artists when making use of materials, objects and practices from the household ambiances in a conceptual expression of "the female practice" and "feminist spaces".

According to Cornelia Parker, the British woman artist, the concept of the art of installations is typically female, among other things also because the installations is enclosed "it is entered into and one walks through it (same as 
through the house)"21; the need to participate and the fluid role of our experience in the art of installations constitutes the "femininity" of the approach both in the opinion, and also in the attitude towards this type of art. Cornelia Parker denies any direct identification with the feministic positions in her work, however she is in pursuit of the positive meanings of "femininity" based primarily on the idea that the woman in cultural and biological conditions has been developing and perfecting certain sensory abilities which quite well corresponded to the production of the art of installations. Such aspects are also contained in her work Cold, dark matter: An Exploded View dating 1997, the work which initially started as a garden shed filled up with garden tools, house garbage, and an assortment of books selected with great care (among others with Proust's "In Search of the Lost Time"); after having taken photographs of it, the woman artist had the British Army blast the shed with explosives, and thereafter reassembled the parts and hung them on the ceiling of the gallery in the center of which she placed a $200 \mathrm{~W}$ bulb: to have the shed destroyed by explosives and hang its remnants (fragments) on the ceiling meant to emphasize the concept of such space as the refuge (sanctuary) and shelter in the process of the rite of man's growing up. It here concerns the space of "female" art - the installations which treats the private space of the" masculine" - by a "feminine" approach in the opinion of the artistic work.

Artistic interpretation with simple things and materials is typical for those who spend much time at home; the women living for centuries in a domestic environment constantly pondering the significance of their heritage, however also weaving the history - the things which for centuries have been around them bear the touches of their female ancestors, as handed down from the mother to the daughter.

Long before now

a long time ago

before you were born

your great grandmothers

and their sisters and aunts and grandmothers

thought to your future ${ }^{22}$

«I am thinking of writing a story about the American squatters in Venice» ${ }^{23}$ was written by Kiki Smith in May, 2004, a year before the exhibition Homespun Tales at Venice Biennale in 2005. Exhibited in the Querini Museum in Venice, this work establishes the relation between various histories, cultures and eras: the past is represented by the second storey which has inherited the European culture - and which inspired the author's idea - and contains porcelain and Pietro Longhi's paintings, depicting numerous scenes from the bourgeois life, 
whereas the present is shown by the imaginary American house dating back to the eighteenth century on the storey above. In the large central room there is a long wooden table on which some twenty small sculptures in white porcelain inspired by the women of the eighteenth century from Pietro Longhi's paintings are exhibited. Preoccupied with the everyday items found in the house, the female artist weaves the fragmentized story of the home-feeling.

"The truth is, that I feel I am at home only in the world I have created myself." 24

Kiki Smith emphasizes the autobiographic elements in her work and reminiscences of the happy childhood moments she spent helping her father sculpt his work; her family has been living in the house in front of which there lay the tombstone of a remote ancestor (like "The Addams Family"), whereas she was spending her time moving the furniture from one side of the house to another and believed that everything possessed its won mobility, and that the American colonial house could therefore exist in Venice..$^{25}$

Unlike her, Louise Bourgeois, in her work, utilizes the reminiscences of the traumas from her childhood, particularly as it pertained to her difficult relationship with her father. At the beginning of her career, Louise Bourgeois was making the drawings in which the house architecture existed to separate a part of the body. Femmes Maisons, the drawing dating 1940 presented a female nude body which instead of the head and part of the torso had a house ${ }^{26}$ - some parts of the body have been amputated and abandoned their space for the architecture of the house. This drawing of the house operates with multiple connotations and symbolic associations: the house provides a symbolic shelter from outside traumas, but at the same time it controls the traumas by sealing them away; it protects yet also traumatizes the body.

The contemporary installations can thus be discussed as the works which situate the observers in their center, "frame him in", and above all confuse him in his own experience of space. For example, Louise Bougeois' installations Passage Dangereux dating from 1997, aside from making the observer feel both inside and outside of oneself at the same time, it, as well as her art in general, is filled with objects that reconstruct her own house: they are little chests, small boxes, letters, clothes, toys which resonate with painful reminiscences taking part at the same time in the process of healing. Besides, her work juxtaposes strange, seemingly incompatible objects, sexually provocative situations and evokes the painting art and objects of surrealism. One of such works is also the work of Meret Oppenheim Breakfast in Fur from 1936, the cup and the saucer lined 
with fur which combine sensuality and corporal (physical) associations with the mass-production consumer goods. Fur lined is also the bedroom of Lina Loos, the wife of Adolf Loos, the room which is a warm sac which one can wrap oneself with ${ }^{27}$ This Adolf Loose's interior has a pre-Oedipus character: these are the spaces that cover their tenants just as the clothes cover the body, and his interior architecture is 'the architecture of pleasure', 'the architecture of womb'.

Nowadays, being already part of the history of art, House of Reachel Whiteread from 1993, also seizes the idea of the house as maternal, but also as a womb's. ${ }^{28}$ Unlike Kiki Smith who expressed her reminiscences of the house through small, fragile and private objects, Whiteread prepares a huge, major, public work, a project of the private history, reminiscences, associations... This sculptor's positive/negative form which for some time existed in 193 Grove Road in the East Side London, is a work related to absence and on departure, however, at the same time also the simulacrum. ${ }^{28}$

The connection of the previous work of Reachel Whiteread with the feminists movement was most often found in her beds and bath tubs casts, however it was rarely connected to the House. Doreen Massey sees the work in empty/full and public/private binaries: "The private, inner world of the house is also exposed to the public view and is conclusive, as if clearly underlying the intention to separate the categories of the public (male) and private (female)... Not only is the physical space turned upside down, but the entire charge of meanings and metaphors borne by this space. ${ }^{229}$ Rarely mentioned importance of work is also that it returned the art to the street and indicated to its presence, as well as suggested that there existed other aspects of life except the everyday one. Even though the artist herself does not define her work as part of the feministic history and does not think that it is political in that sense, her work embodies the dialectics of liberation of women in the twentieth century opposite nineteenthcentury Victorian repression. In that sense, the work marks the reminiscence of time $\mathrm{e}^{30}$ in a fascinating manner: the picture of the inside of a nineteenthcentury house was pushed back by the picture of the external world of the twentieth-century, in which the privacy, domesticity, almost literary attempts to break its mould and free itself.

It is possible by reading the work in a feministic manner within the context of the history of art to discover post-minimalism in it, as female territory versus male unemotional minimalism. Like minimalism using modularity and repetition, so does also the post-minimalism of Reachel Whiteread through 
repetition (eg. Windows) and modularity (stairways). House, is therefore, also the discussion on the position of women, and also the response of the British artist to the American male minimalism, and embodiment of the irreversible past.

Reachel Whiteread was one of the young British artists-yBa who started in 1988 with the "freeze" exhibition and were immediately qualified as artistic phenomenon. Emerging from the underground scene, they were not, however, seen as " political animosity of the children of the Thatcher's" ${ }^{11}$ Besides that, the artistic contextual status was marked also by the fact that she was the daughter of the less known artist Pet Whiteread (and that she was not Without the name and without friends ${ }^{32}$ ) who, however, in seventies organized a significant feminist exhibition Women's Images of Men, which is convincingly in favor of the fact that most often the life of the female artists has been marked since their birth by the context of creative and highly educated family, unlike the male artists who most often originated from the rural and poverty environments.

\section{CONCLUSION}

From the painting by Emily Mary Osborn Nameless and Friendless to the works of Kiki Smith and Reachel Whiteread the span of time amounts to only one-hundred-and-fifty years. According to the works of Linda Nohlin there is no doubt that "Osborn, being a smart and popular provider of the Victorian public with the paintings of acceptable genre, accepted " the natural" presumptions of the Royal Academy which stated that home and family were the right environment for a reputable young woman"33, and therefore, the painting, which was the image of the poor woman artist who was humbly offering the painting to a trader, was chosen by her as the text by means of which she defined this situation as the expression of misfortune, and not of the young artist's power who was forced by distress " into the dangerous public area of professionalism" 34 . At the end of the twentieth century female artists no longer and for quite some time acclaimed the presumptions of the private space of home and family as the only exclusively space for women on the contrary, they are now "dealing with the house" in the art not any longer as in the past by painting previously inaccessible spaces of femininity, but find in it (in the house) the answer to the issue of gender by making polemics equally with the tradition as well as with the mainstream, sometimes erecting it from its very foundations. 

Papic, Zarana, Sociologija i feminizam. Savremeni pokret i misao o oslobodjenju zena i njegov uticaj na sociologiju,Beograd, IIC SSOS, 1989, p. 71

The gender identity is the biological identity which has been represented through the system of culturological presentations.

De Beauvoir defended the thesis on woman as the object of man's culture deprived of the right to subjectivity. See re this Beauvoir, Simone de, Drugi pol, BIGZ, Beograd, 1982

The notion gender stands instead of the notion sex, as a cardinal point of the early feminism the notion of gender refers to the social origin of the identity of men and women, to the system of connections which may, but are not directly determined by sexuality. The very sexual difference is a political difference; the sexual difference is the difference between the freedom and subordination Alberti, Leon Battista, TheTten Books of Architecture, The 1755 Leoni Edition, Dover Publications, Inc., New York, p. 107 
The House of Dolls (Nora), the drama by Henrik Ibsen. The drama at the beginning, when Nora was a little doll of her husband Torvald is named The House of Dolls, however, at the end, the doll becomes a person with a first and last name: Nora A Room of One's Own, an Essay by Virginia Wolf Pollock, Griselda, Modernost i prostori zenskosti, u Feministicka likovna kritika i teorija likovnih umetnosti, Centar za zenske studije, Zagreb, 1999.

Actually, it has never been granted either until women have taken it. Pollock, Griselda, Modernost i prostori zenskosti,u Feministicka likovna kritika I teroija likovnih umetnosti, Centar za zenske studije, Zagreb, 1999., p. 174.

Ibid., p. 187.

It is interesting, as stated by Pliny the Elder (Gaius Plinius Secundus Maior), that the mythical origination of painting art is linked to the moment when the young Koricanka drew the outlined shadow of her departing lover on the wall, and thus, accordingly, the first painting was made by a woman inspired by the man motive.

Also, the myth does not concern the open architecture, but points to the drawing as a motivated event, as a procedure, activity

Pollock, Griselda, Pollock, Griselda, Modernost i prostori zenskosti, u Feministicka likovna kritika I teroija likovnih umetnosti, Centar za zenske studije, Zagreb, 1999., p. 187.

See, for eg. Albreht Dürer, Sveti Jeronim u svom studiju, 1514. a standard interpretation of a Renaissance studio

The word closet. "We doe call the most secret place in the house appropriate unto our private studies... a closet.” A. Day, English Secretary (1586), quoted according to Wigley, Mark, Untitled: the Housing of

Contemplating about what would have been had Shakespeare had a sister, Virginia Wolf wrote: “...let me imagine that Shakespeare had a miraculously gifted sister, which was, let us say, called Judith...she was equally brave, equally imaginative, equally willing to see the world like him... One summer night she collected some of her effects into a bundle, climbed down a rope and started for London... in the end Nick Green, the leader of the actor's company took pity on her; after she had found she was pregnant with that gentleman - who would measure the excitement and fierceness of the poet's heart imprisoned and restrained in the female body? - she committed suicide one winter night; was buried at the cross-roads, in the place where buses stop in front of the Elephant and Castle." Wolf, Virginia, Sopstvena soba, Plavi jahac, Beograd, 2003, pp. 55-56 Wolf, Virginia, Sopstvena soba, Plavi jahac, Beograd, 2003, p.1.

Colomina, Beatriz,The Split wall: Domestic Voyeurism, in Sexuality and Space, ed. By Beatriz Colomina, princton Papers of Architecture, new York, 1992, p.79.

Perry Gill, Dream house: installations and the home, in Perry G. and Wood. P., (ed), Themes in Contemporary Art, 2004., Yale University Press, New Haven and London, p.243.

Smith, Kiki, Homespun Tales, Fondatione Querini Stampalia, Venezia, 2005., p.98.

Ibid., p. 152.

Sherrill, Steven, Kiki\&Me. Kiki Smith: glad to be a terror, Modern Painters( July/August 2005.) p.79.

http://www.pbs.org/art21/artists/smith/clip2.html 18.10.2005.

In this place there stands a remote, however, still an association with the work of Marina Abramovic exhibited at the Venice Biennale where the artist named her creative process as the house cleaning - for her the house presents a body which should be cleaned prior to the artist taking up creative work.

Quoted according to José Quetglas, "Lo Placentero", Carrer de la Cuitat, no 9-10, special issue on Loos (January 1980): 2 in Columina, Beatriz, The Split wall: Domestic Voyeurism, in Sexuality and space, ed by Beatriz Colomina, Princton Papers of Architecture, New York, 1992., p. 92.

It is without doubt that the House in itself, on different levels, cements also - the death; work "Ether" form 1990 and "Untitled (Orange Bath") bear the reminiscence of the Greek sarcophaguses 
or posthumous masks. In this place the rhyme womb/tomb is eloquent, which already John Keats, writing about the cloud, had "Like a child from the womb, like a ghost from the tomb".

"The transition from the signs concealing something to the signs concealing that there was nothing signify a decisive turn." Bodrijar, Jean, simulacrums and simulation, IP Svetovi, Novi sad, 1991 Perry, Gill, Dream house: installations and the home, in Perry, G. and Wood.P., (ed), Themes in Contemporary Art, 2004., Yale University Press, New Haven and London, p.259.

time like the „grand sculptor“ of Margaret Jursenar; see Jursenar, Margaret, Vreme, taj veliki vajar, u Izabrani ogledi, Nolit, Beograd, 1990.

Mercer Kobena, Ethnicity and Internationality, in The Vizual Culture Reader, second ed. by Nicholas Mirzoeff, London and New York, 2004. p.191. umetnost, Beograd, 2002. str.138.

ibid New York

Colomina, Beatriz, The Split Wall: Domestic Voyeurism, in Sexuality and space, ed. by.Beatriz Colomina, Princton Papers of Architecture, New York, 1992.

Mercer, Kobena, Ethnicity and Internationality, in The Visual Culture Reader, second ed. ed by Nicholas Mirzoeff, London and New York, 2004.

Nohlin, Linda, Žene, umetnost i moć, u Uvod u feminističke teorije slike, Centar za savremenu umetnost, Beograd, 2002.

Pollock, Griselda, Modernost i prostori ženskosti, u Feministička likovna kritika i teorija likovnih umetnosti, Centar za ženske studije, Zagreb, 1999.

Perry, Gill, Dream house: installations and the home, in Perry, G. and Wood.P., (ed), Themes in Contemporary Art, Yale University Press, New Haven and London, 2004.

Smith, Kiki, Homespun Tales, Fondatione Querini Stampalia, Venezia, 2005.

Sherrill,Steven, Kiki \& Me. Kiki Smith: glad to be a terror, Modern Painters ( July/ August 2005.) p79

Vulf, Virdžinija, Sopstvena soba, Plavi jahač, Beograd, 2003.

Wigley, Mark, Untitled: The Housing Of Gender in Sexuality and space, ed. by.Beatriz Colomina, Princton Papers of Architecture, New York, 1992 